\title{
Secondary Hemophagocytic Lymphohistiocytosis in an Infant with Wolman Disease
}

\author{
WoIman Hastalığı Olan Bir Bebekte Gelişen İkincil Hemafagositik Lenfohistiyositozis
}

\begin{abstract}
${ }^{1}$ Şevket Yılmaz Training and Research Hospital, Clinic of Pediatric Metabolism, Bursa, Turkey
${ }^{2}$ Şevket YIImaz Training and Research Hospital, Clinic of Pediatric Hematology, Bursa, Turkey

${ }_{3}^{3}$ Şevket Yılmaz Training and Research Hospital, Clinic of Pediatrics, Bursa, Turkey

${ }^{4}$ Şevket YIlmaz Training and Research Hospital, Clinic of Pediatric Nephrology, Bursa, Turkey

${ }_{5}^{5}$ Sevket YIlmaz Training and Research Hospital, Clinic of Pediatric Neurology, Bursa, Turkey
\end{abstract}

Aynur Küçükçongar Yavaş ${ }^{1}$, Betül Orhaner ${ }^{2}$, Pınar Genç ${ }^{3}$, Nevin Kılıç3 ${ }^{3}$ Hakan Erdoğan ${ }^{4}$, Özlem Özdemir ${ }^{5}$, Arzu Ekici $^{5}$

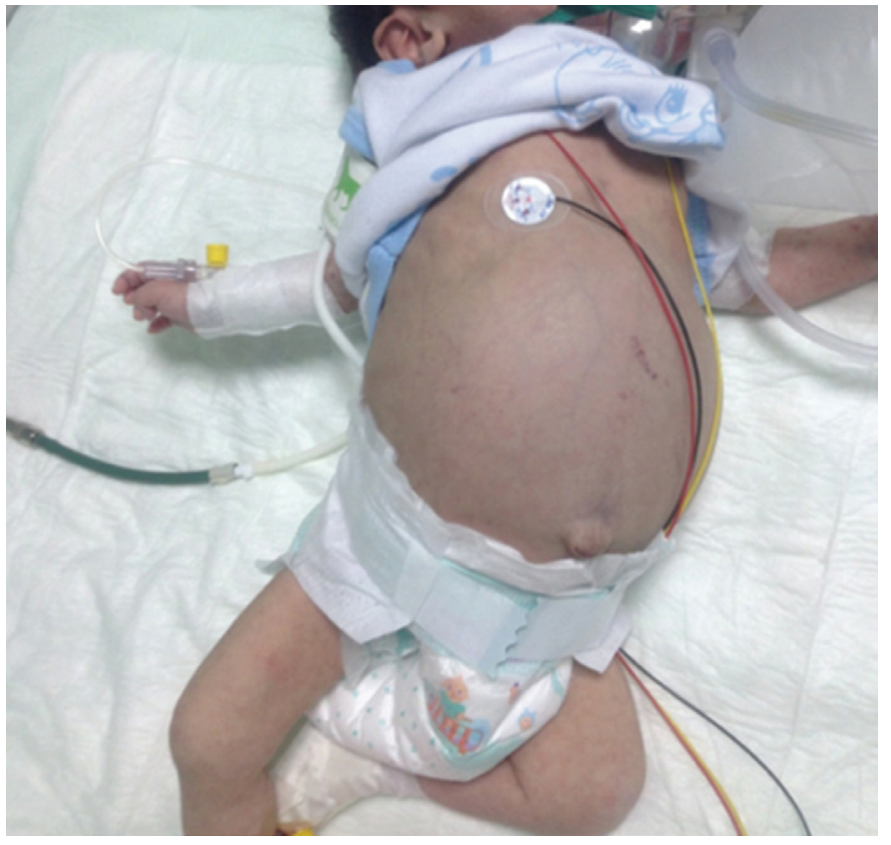

Figure 1. Two-month-old female patient with Wolman disease, showing abdominal distension.

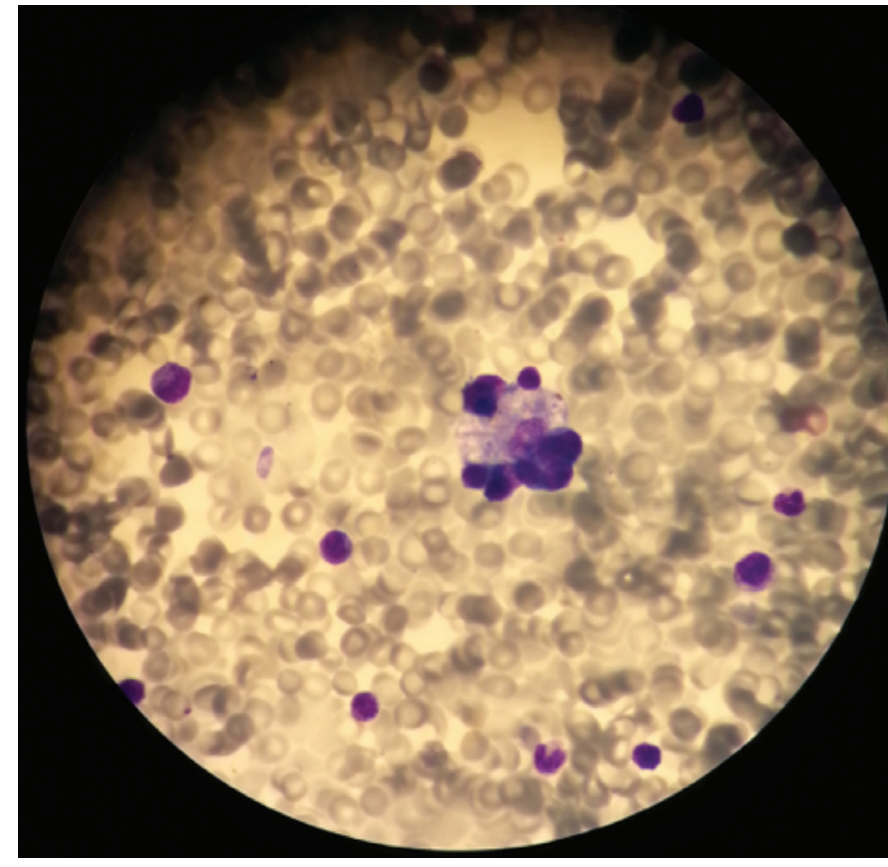

Figure 2. Hemophagocytosis in the bone marrow of our patient.
A 2-month-old girl presented with vomiting, fever, failure to thrive, and diarrhea. She was born to consanguineous parents. She was irritable and pale and she had hepatosplenomegaly (Figure 1). Her weight and height were below the $3^{\text {rd }}$ percentile. Initial hemoglobin count was $7.6 \mathrm{~g} / \mathrm{dL}$, white blood cell count was $12 \times 10^{9} / \mathrm{L}$, platelet count was $92 \times 10^{9} / \mathrm{L}$, triglyceride level was 361 $\mathrm{mg} / \mathrm{dL}$ (reference range: $40-150 \mathrm{mg} / \mathrm{dL}$ ), and ferritin level was
$>1650 \mathrm{ng} / \mathrm{mL}$. According to bone marrow aspiration, numerous examples of hemophagocytosis were observed (Figure 2). She was diagnosed with hemophagocytic lymphohistiocytosis (HLH) because of prolonged fever, organomegaly, bicytopenia, high levels of ferritin, and bone marrow findings. Enzymatic analyses were performed for lipid storage disorders. The lysosomal acid lipase (LAL) activity was $<0.02 \mathrm{nmol} /$ punch/h (reference range:

${ }^{\odot}$ Copyright 2017 by Turkish Society of Hematology

Turkish Journal of Hematology, Published by Galenos Publishing House

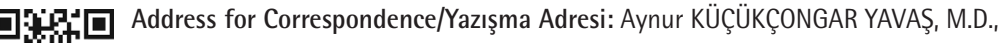

Şevket Yılmaz Training and Research Hospital, Clinic of Pediatric Metabolism, Bursa, Turkey

Phone : +905355725741

E-mail : aynurcon@yahoo.com
Received/Geliş tarihi: December 31, 2015 Accepted/Kabul tarihi: March 16, 2016 
0.07-2.3 nmol/punch/h). Based on reduced LAL activity, she was diagnosed with Wolman disease. Although treatment and supportive therapy were applied, the patient died 1 month later.

Exon 4 heterozygous variation was found at the LIPA gene location c:260G>T (GGC>GTC), p.Gly87Val. Sequence analysis of all coding regions of the LIPA gene presented heterozygote NM_000235(LIPA_vENST00000336233):c.260G>T(p.Gly87Val) variation in both parents. This variation was reported as a disease-causing variant by Pagani et al. [1].

It was discussed in cases of Wolman disease that the pathophysiological role of cholesteryl ester induces inflammasome activation in macrophages, leading to secondary HLH [2].

Keywords: Wolman disease, Hemophagocytic lymphohistiocytosis, Hemophagocytosis
Anahtar Sözcükler: Wolman hastalığı, Hemafagositik lenfohistiyositozis, Hemofagositoz

Informed Consent: It was received from the parents.

Conflict of Interest: The authors of this paper have no conflicts of interest, including specific financial interests, relationships, and/or affiliations relevant to the subject matter or materials included.

\section{References}

1. Pagani F, Garcia R, Pariyarath R, Stuani C, Gridelli B, Paone G, Baralle FE. Expression of lysosomal acid lipase mutants detected in three patients with cholesteryl ester storage disease. Hum Mol Genet 1996;5:1611-1617.

2. Taurisano R, Maiorana A, De Benedetti F, Dionisi-Vici C, Boldrini R, Deodato F. Wolman disease associated with hemophagocytic lymphohistiocytosis: attempts for an explanation. Eur J Pediatr 2014;173:1391-1394. 